\title{
OPEN The combined effect of coating treatments to nisin, nano-silica, and chitosan on oxidation processes of stored button mushrooms at $4^{\circ} \mathrm{C}$
}

\author{
Rokayya Sami ${ }^{1 凶}$, Abeer Elhakem ${ }^{2}$, Mona Alharbi ${ }^{2}$, Nada Benajiba $^{3}$, Mohammad Fikry $^{4}$ \& \\ Mahmoud Helal ${ }^{5}$
}

Agaricus bisporus is an edible fungus with a limited shelf life due to high moisture loss, browning, respiration, self-dissolve, lack of physical protection, rotting, and microbial attack. Mushrooms have been coated with nisin, nano-silica, and chitosan films in order to extend the shelf life, preserve quality and oxidation activities. The results showed that treating the mushrooms with chitosan and nano-silica (CH-AN-SILICA) increased superoxide dismutase activity (SOD-6.53 $\mathrm{U} \mathrm{kg}^{-1}$ ), total phenolic content (TPC $-0.39 \mathrm{~g} \mathrm{~kg}^{-1}$ ), and malondialdehyde content (MDA-1.63 $\mu \mathrm{mol} \mathrm{kg}{ }^{-1}$ ). CH-ANSILICA treatment exhibited the highest scavenging against 2,2-Diphenyl-1-picrylhydrazyl (DPPH) and 2,2'-azino-bis(3-ethylbenzothiazoline-6-sulfonic acid) (ABTS) radicals. While, CH-AN-SILICA with the addition of nisin as an antimicrobial agent preserved almost the reactive oxygen species such as hydroxyl radicals $(\mathrm{OH}-0.33 \mu \mathrm{mol} \mathrm{g}-1)$, superoxide anion $\left(\mathrm{O}_{2}{ }^{--}-0.271 \mathrm{mmol} \mathrm{s}^{-1} \mathrm{~kg}^{-1}\right)$, and hydrogen peroxide $\left(\mathrm{H}_{2} \mathrm{O}_{2}-21.54 \mu \mathrm{mol} \mathrm{g}{ }^{-1}\right)$. Besides, both CH-AN-SILICA and CH-AN-SILICA/N enhanced the catalase (CAT) activity and reduced the respiration rate. The results indicated that the combination of nisin, nano-silica, and chitosan coating films was effective in providing a longer storage life with acceptable quality in mushrooms.

Button mushrooms (Agaricus bisporus) are abundantly popular edible mushrooms with a significant commercial potential due to their valuable nutrients including proteins, main amino acids, riboflavin, and niacin. Furthermore, the valuable pharmacological, organoleptic, therapeutic bioactive compounds, antibacterial, immunomodulation, and antioxidant effects were noticed ${ }^{1}$. Though, that mushrooms have a limited shelf-life (1-3) days at the commercial temperature, due to several factors such as moisture loss, browning, respiration, self-dissolve, lack of physical protection rotting, and the microbial attack ${ }^{2}$. Browning, active metabolic process, and rapid deterioration especially with the white strains are important indexes that affect the marketing and customer acceptability ${ }^{3}$. Oxidation enzymes play an essential role in catalyzing the phenols hydroxylation to form $o$-diphenols and then $o$-quinones, which negatively influence the browning index, cellular membrane structure, and malondialdehyde content ${ }^{4}$. Besides, reactive oxygen species balance can be destroyed during the storage period followed by low enzymatic antioxidant defense such as superoxide dismutase, peroxidase, and catalase. At present, a variety of preservation methods have been technically performed to delay browning and extend the shelf-life of mushrooms such as chemical washing ${ }^{5}$, UV irradiation ${ }^{6}$, the modified atmosphere ${ }^{7}$, chilling ${ }^{8}$, and biological treatments ${ }^{9}$. On the other hand, there were some side effects for these techniques, such as the potential toxicity, sensory evaluation, and lack of nutrients ${ }^{10}$. Consequently, it is crucial to find out an eco-friendly preservation method to extend the storage time and maintain the quality of mushrooms. Qu et al. ${ }^{11}$, have proposed essential

\footnotetext{
${ }^{1}$ Department of Food Science and Nutrition, College of Sciences, Taif University, P.O. 11099, Taif 21944, Saudi Arabia. ${ }^{2}$ Department of Biology, College of Science and Humanities in Al-Kharj, Prince Sattam Bin Abdulaziz University, Al-Kharj 11942, Saudi Arabia. ${ }^{3}$ Department of Basic Health Sciences, Deanship of Preparatory Year, Princess Nourah Bint Abdulrahman University, P.O. Box 84428, Riyadh 11671, Saudi Arabia. ${ }^{4}$ Department of Agricultural and Biosystems Engineering, Faculty of Agriculture, Benha University, Moshtohor, Toukh 13736, Qalyoubia Governorate, Egypt. ${ }^{5}$ Department of Mechanical Engineering, Faculty of Engineering, Taif University, P.O. 11099, Taif 21944, Saudi Arabia. ${ }^{\circledR}$ email: rokayya.d@tu.edu.sa
} 


\begin{tabular}{|l|l|l|l|l|l|}
\hline & Days & Control/M & CH-AN & CH-AN-SILICA & CH-AN-SILICA/N \\
\hline \multirow{5}{*}{ POD $\left(\mathrm{Ukg}^{-1}\right)$} & 0 & $0.003 \pm 0.000^{\mathrm{e}}$ & $0.003 \pm 0.000^{\mathrm{e}}$ & $0.003 \pm 0.000^{\mathrm{e}}$ & $0.003 \pm 0.000^{\mathrm{e}}$ \\
\cline { 2 - 6 } & 3 & $0.005 \pm 0.001^{\mathrm{d}}$ & $0.006 \pm 0.001^{\mathrm{d}}$ & $0.007 \pm 0.001^{\mathrm{d}}$ & $0.007 \pm 0.001^{\mathrm{d}}$ \\
\cline { 2 - 6 } & 6 & $0.007 \pm 0.002^{\mathrm{b}}$ & $0.007 \pm 0.003^{\mathrm{b}}$ & $0.009 \pm 0.001^{\mathrm{b}}$ & $0.009 \pm 0.003^{\mathrm{b}}$ \\
\cline { 2 - 6 } & 9 & $0.011 \pm 0.001^{\mathrm{a}}$ & $0.010 \pm 0.001^{\mathrm{a}}$ & $0.010 \pm 0.003^{\mathrm{a}}$ & $0.010 \pm 0.002^{\mathrm{a}}$ \\
\hline \multirow{5}{*}{ SOD $\left(\mathrm{Ukg}^{-1}\right)$} & 12 & $0.009 \pm 0.003^{\mathrm{c}}$ & $0.007 \pm 0.002^{\mathrm{c}}$ & $0.006 \pm 0.002^{\mathrm{c}}$ & $0.005 \pm 0.001^{\mathrm{c}}$ \\
\hline & 0 & $3.323 \pm 0.006^{\mathrm{c}}$ & $3.323 \pm 0.006^{\mathrm{e}}$ & $3.323 \pm 0.006^{\mathrm{d}}$ & $3.323 \pm 0.006^{\mathrm{d}}$ \\
\cline { 2 - 6 } & 3 & $3.383 \pm 0.007^{\mathrm{b}}$ & $3.550 \pm 0.010^{\mathrm{d}}$ & $3.617 \pm 0.006^{\mathrm{c}}$ & $3.627 \pm 0.006^{\mathrm{c}}$ \\
\hline & 6 & $3.417 \pm 0.005^{\mathrm{a}}$ & $3.593 \pm 0.006^{\mathrm{c}}$ & $3.703 \pm 0.007^{\mathrm{b}}$ & $3.667 \pm 0.004^{\mathrm{bc}}$ \\
\hline & 9 & $3.423 \pm 0.004^{\mathrm{a}}$ & $3.613 \pm 0.005^{\mathrm{b}}$ & $3.717 \pm 0.004^{\mathrm{b}}$ & $3.837 \pm 0.001^{\mathrm{b}}$ \\
\hline \multirow{5}{*}{ CAT $\left(\mathrm{Ukg}^{-1}\right)$} & 12 & $3.413 \pm 0.006^{\mathrm{a}}$ & $3.700 \pm 0.010^{\mathrm{a}}$ & $4.103 \pm 0.032^{\mathrm{a}}$ & $4.150 \pm 0.002^{\mathrm{a}}$ \\
\hline & 0 & $0.224 \pm 0.007^{\mathrm{b}}$ & $0.224 \pm 0.007^{\mathrm{b}}$ & $0.224 \pm 0.006^{\mathrm{b}}$ & $0.224 \pm 0.005^{\mathrm{b}}$ \\
\cline { 2 - 6 } & 3 & $0.325 \pm 0.001^{\mathrm{ab}}$ & $0.352 \pm 0.002^{\mathrm{ab}}$ & $0.391 \pm 0.001^{\mathrm{a}}$ & $0.381 \pm 0.002^{\mathrm{a}}$ \\
\cline { 2 - 6 } & 6 & $0.391 \pm 0.001^{\mathrm{a}}$ & $0.461 \pm 0.001^{\mathrm{a}}$ & $0.450 \pm 0.001^{\mathrm{a}}$ & $0.421 \pm 0.001^{\mathrm{a}}$ \\
\cline { 2 - 6 } & 9 & $0.381 \pm 0.002^{\mathrm{a}}$ & $0.440 \pm 0.001^{\mathrm{a}}$ & $0.491 \pm 0.002^{\mathrm{a}}$ & $0.441 \pm 0.002^{\mathrm{a}}$ \\
\cline { 2 - 6 } & 12 & $0.331 \pm 0.001^{\mathrm{ab}}$ & $0.435 \pm 0.001^{\mathrm{a}}$ & $0.471 \pm 0.001^{\mathrm{a}}$ & $0.469 \pm 0.001^{\mathrm{a}}$ \\
\hline
\end{tabular}

Table 1. Effect of coating on oxidative enzyme activities; POD, SOD, and CAT in $\left(\mathrm{Ukg}^{-1}\right)$. Values within a column (lowercase) are significantly different $(p \geq 0.05)$. The values in parentheses indicate (SD \pm ) standard deviation.

oils due to their antimicrobial effects against the lipophilic properties of the mushroom cells. In recent years, nano-technology coating has been reported for the antioxidant capacities potentially enhancement for several types of foods. Qiao et al. ${ }^{12}$, have proposed nano-coating, thymol, and tween- 80 as antimicrobial agents to delay the oxidation processes on cantaloupes. Sami et al. ${ }^{13}$, applied nano-coating, chitosan, and nisin for the inhibition of polyphenol oxidase and peroxidase activities on blueberries. The American Food and Drug Administration (FDA) had declared that nano-silica dioxide, less than $2 \%$ by weight of the food is safe to be used as a food additive in food preservation and industry ${ }^{14}$. Limited studies have been described the effects of coating treatments on the oxidation processes of button mushrooms during postharvest storage. Thus, due to the limited shelf-life of mushrooms, it is needed to focus on the biochemical changes such as respiration, and production rates with the measurement of bioactive components and antioxidant activities, reactive oxygen species, and malondialdehyde contents to prolong the shelf-life.

\section{Results}

Effect of coating on oxidative enzyme activities. Table 1 presents the effect of coating on oxidative enzyme activities. Peroxidase activity (POD) results during storage, raised to the greatest activity on the 9th day, and then hurriedly reduced. However, $\mathrm{CH}$-AN-SILICA/N treatment $\left(0.005 \mathrm{U} \mathrm{kg}^{-1}\right)$ significantly $(p<0.05)$ inhibited POD activity during the thorough storage period that might avoid the melanin synthesis at the mushroom browning process. Superoxide dismutase activity (SOD) in treated mushrooms radically increased and existed higher than Control/M samples, (Table 1). CH-AN-SILICA/N reported the highest value of SOD activity (4.15 $\left.\mathrm{U} \mathrm{kg}^{-1}\right)$. CAT activity of mushroom samples coated with CH-AN-SILICA and CH-AN-SILICA/N films reported equal values $\left(0.47 \mathrm{U} \mathrm{kg}^{-1}\right)$. Mushrooms treated with $\mathrm{CH}-\mathrm{AN}$ film only reported $\left(0.44 \mathrm{U} \mathrm{kg}^{-1}\right)$ lower CAT activity after 12 days of storage $(p<0.05)$.

Effect of coating on TPC and MDA. Figure la presents the total phenolic content converted into nisin, nano-silica, and chitosan in the mushroom samples depending on the storage period. The initial TPC in fresh mushroom samples was counted $\left(0.34 \mathrm{~g} \mathrm{~kg}^{-1}\right)$. As a result, the increase of that consideration was minor, reaching $\left(0.38-0.43 \mathrm{~g} \mathrm{~kg}^{-1}\right)$ on the first 3 days of the storage, directly after applying the coatings. The highest statistically significant TPC rise was reported in the mushroom samples earlier subjected to CH-AN-SILICA coating at the end of the storage time. The MDA values in both Control/M and $\mathrm{CH}-\mathrm{AN}$ mushrooms increased during the stor-

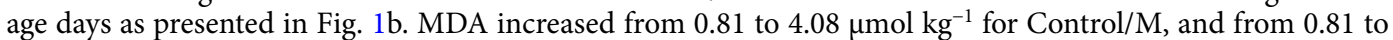

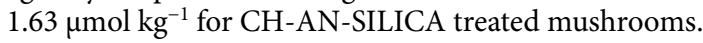

Effect of coating on respiration rate. Figure 2 shows the respiration rate changes during storage after various coating treatments on button mushroom samples. The respiration rate was first raised and then reduced during the storage period. The mushrooms treated with $\mathrm{CH}-\mathrm{AN}-\mathrm{SILICA}$ or even $\mathrm{CH}-\mathrm{AN}-\mathrm{SILICA} / \mathrm{N}$ films reported the lowest value $\left(0.005 \mathrm{mg} \mathrm{CO}_{2} \mathrm{~kg}^{-1} \mathrm{~s}^{-1}\right)$ at the end of 12 days of the storage period.

Effect of coating on antioxidant capacity. ABTS and DPPH radical scavenging capacities in Control/M and treated mushrooms are presented in Fig. 3. In the current work, the initial antioxidant capacities immediately following the harvest were 52.26 and $52.14 \%$, respectively. The results for ABTS radical scavenging increased and then declined at the end of the storage to reach a level of (71.09 and 70.03\%) for CH-AN-SILICA and CH-AN- 


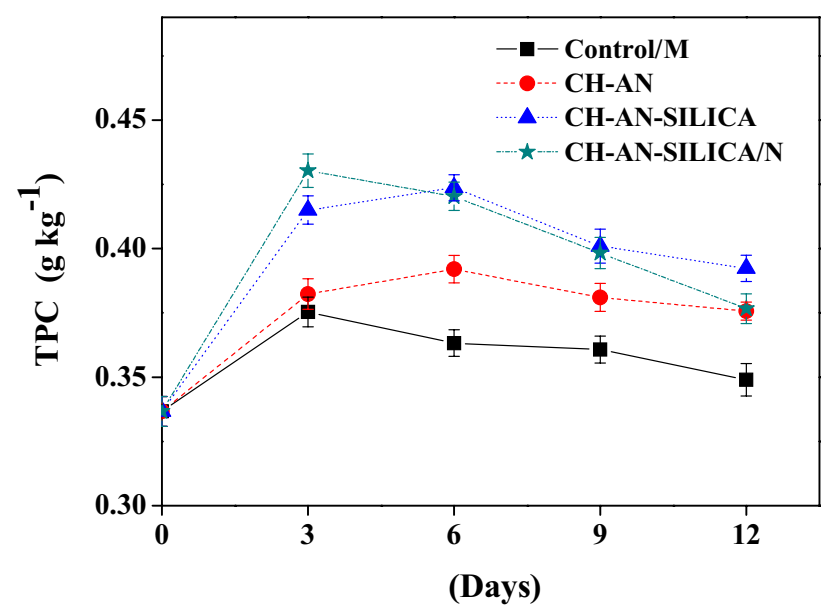

a

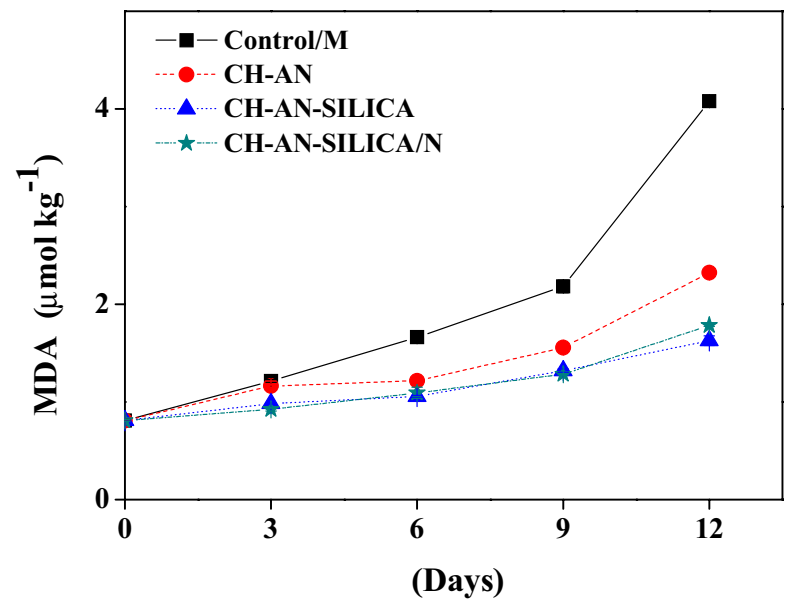

b

Figure 1. Effect of coating on (TPC, $\left.\mathrm{g} \mathrm{kg}^{-1}\right)(\mathbf{a})$ and $\left(\mathrm{MDA}, \mu \mathrm{mol} \mathrm{kg}{ }^{-1}\right)(\mathbf{b})$.

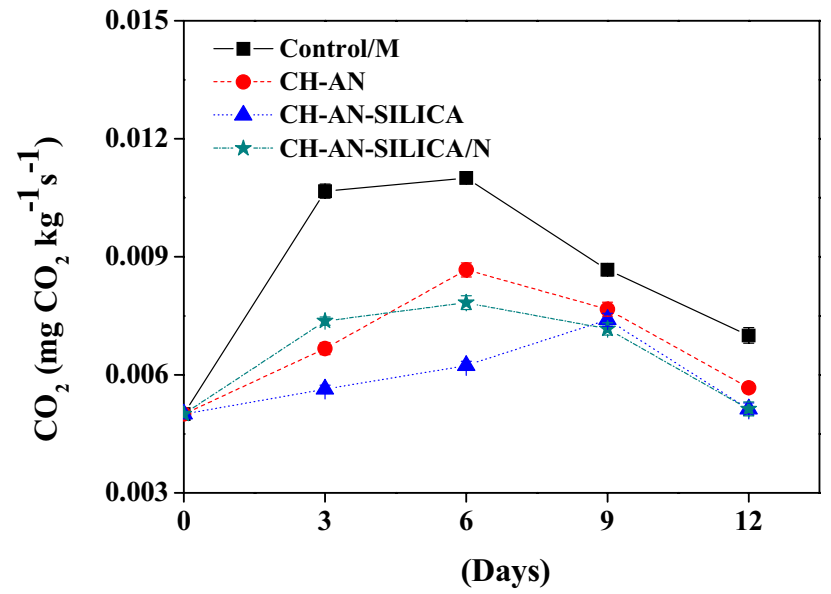

Figure 2. Effect of coating on respiration rate in $\left(\mathrm{mg} \mathrm{CO}_{2} \mathrm{~kg}^{-1} \mathrm{~s}^{-1}\right)$. 


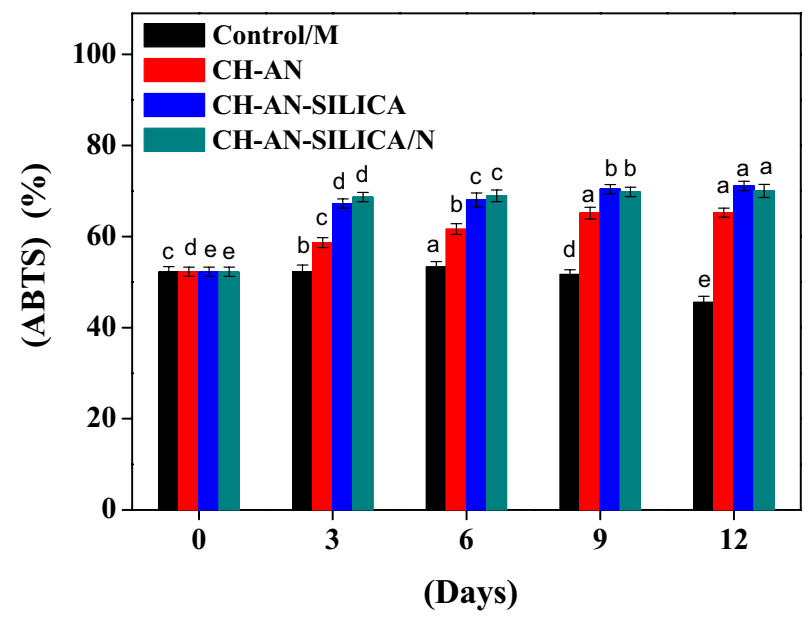

a

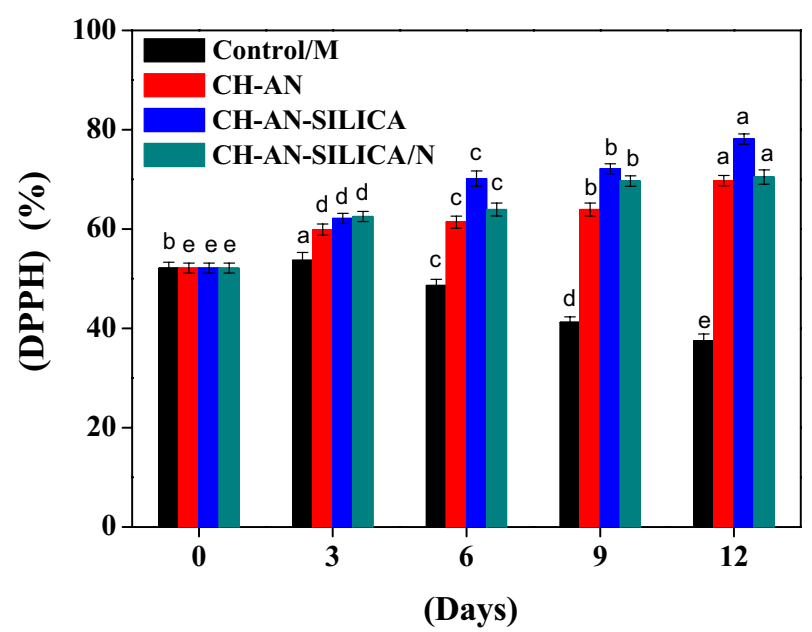

b

Figure 3. Effect of coating on antioxidant capacity; (ABTS, \%) (a), (DPPH, \%) (b).

SILICA/N treatments, respectively, Fig. 3a. The DPPH radical scavenging capacity of treated mushroom samples was evaluated and compared to Control/M samples. CH-AN-SILICA treatment exhibited the highest scavenging against (DPPH) radicals (78.13\%), Fig. 3b. However, the Control/M scavenging activity on the same day was $37.49 \%$.

Effect of coating on $\mathrm{OH}, \mathrm{O}_{2}{ }^{-}$, and $\mathrm{H}_{2} \mathrm{O}_{2}$. $\mathrm{OH}$ values were differentiated between the coating treatments at the end of the storage time $\left(0.18-0.33 \mu \mathrm{mol} \mathrm{g}^{-1}\right)$, where the lowest values were detected in (CH-AN-SILICA) and $(\mathrm{CH}-\mathrm{AN}-\mathrm{SILICA} / \mathrm{N})$ films, Fig. $4 \mathrm{a}$. The $\mathrm{O}_{2}{ }^{\cdot-}$ production rate harshly increases during the storage period from $\left(0.022-0.271 \mathrm{mmol} \mathrm{s}^{-1} \mathrm{~kg}^{-1}\right)$ in Control/M samples, Fig. $4 \mathrm{~b}$. The augmentation of $\mathrm{O}_{2}{ }^{--}$production rate was clear in the first 3 days for all the groups then declined after 6 days of the storage period. Among all the treatments, mushroom samples coated with $\mathrm{CH}-\mathrm{AN}-\mathrm{SILICA} / \mathrm{N}$ reported the lowest $\mathrm{O}_{2}{ }^{-}$production rate and greatly inhibited the increase of $\mathrm{O}_{2}{ }^{--}$production rate in mushroom samples. $\mathrm{H}_{2} \mathrm{O}_{2}$ is responsible for the mushroom senescence and the destruction of cell integrity ${ }^{15}$. The $\mathrm{H}_{2} \mathrm{O}_{2}$ levels in mushroom samples treated with various coating treatments and stored for 12 days are shown in Fig. $4 \mathrm{c}$. The results showed that there was a great increase in $\mathrm{H}_{2} \mathrm{O}_{2}$ values, especially in Control/M samples during storage. $\mathrm{CH}-\mathrm{AN}$-SILICA/N treatment followed by $\mathrm{CH}$ AN-SILICA and CH-AN films reduced as compared to Control/M which were nearly doubled (41.24 $\mu \mathrm{mol} \mathrm{g}-1)$.

\section{Discussion}

POD, SOD, and CAT were evaluated during cold storage to control the oxidative stress balance caused by coating treatments to nisin, nano-silica, and chitosan. The quality characteristics were beginning to deteriorate after $3 \mathrm{rd}$ day due to oxidative enzymes which may perhaps change the color, odor, and taste.POD enzyme can associate with the browning index of a variety of fruits and vegetables ${ }^{4}$. Browning can be influenced by the oxidation of the phenolic substance and result in forming a brown-colored pigment as POD activity can hasten the browning 


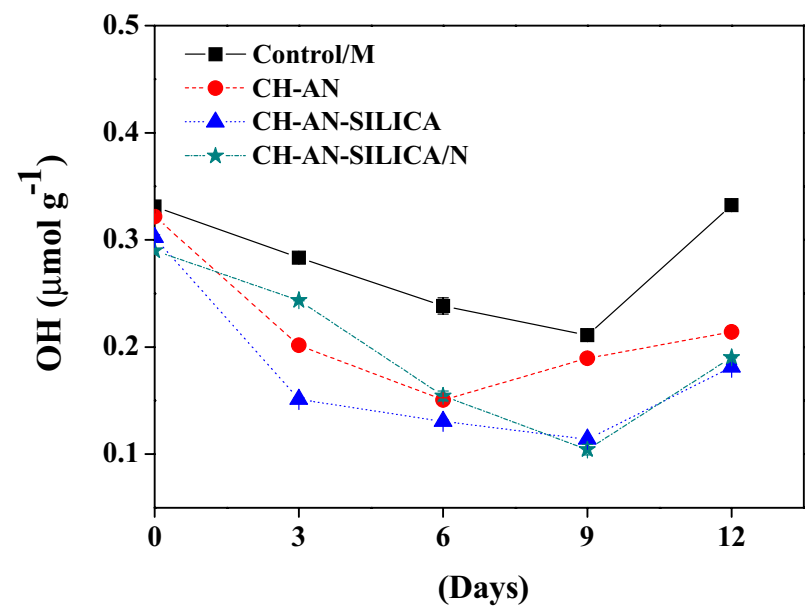

a
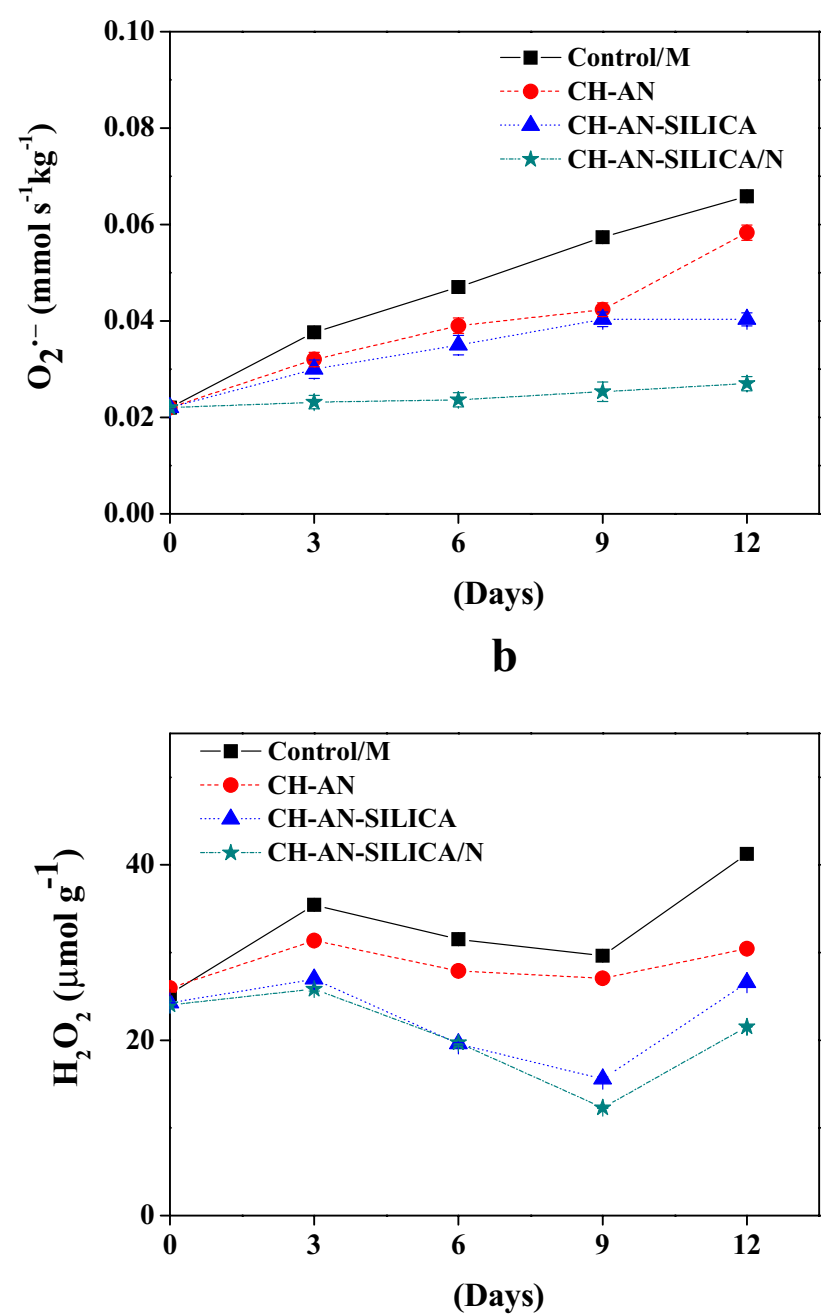

c

Figure 4. Effect of coating on reactive oxygen species; $\left(\mathrm{OH}, \mu \mathrm{mol} \mathrm{g}^{-1}\right)(\mathbf{a}),\left(\mathrm{O}_{2}{ }^{--}, \mathrm{mmol} \mathrm{s}^{-1} \mathrm{~kg}^{-1}\right)(\mathbf{b})$, and $\left(\mathrm{H}_{2} \mathrm{O}_{2}\right.$, $\left.\mu \mathrm{mol} \mathrm{g} \mathrm{g}^{-1}\right)(\mathbf{c})$. 
reactions ${ }^{16}$. Moreover, the coating film with the addition of nisin can fill the groove of the POD active site between hydrogen bonds and $\Pi$-sigma, or even $\Pi$ - $\Pi$ interactions ${ }^{13}$. The current results are in agreement with Karimiradet $\mathrm{al}^{2}$, who reported that POD activity had lower values after the oil coating treatments compared to the control, which might be due to minor oxidative stress retardant enzymatic discolorations. High SOD activity levels can reduce the free radical aggregation by $\mathrm{H}_{2} \mathrm{O}_{2}$ formation as the superfluous $\mathrm{H}_{2} \mathrm{O}_{2}$ should convert into non-toxic molecules ${ }^{17}$. In the case of CAT activity, it may be able to decrease the oxidative damage caused by $\mathrm{H}_{2} \mathrm{O}_{2}$ production in mushrooms ${ }^{18}$. Ding et al. ${ }^{1}$, reported a similar tendency for CAT activity on treated mushrooms. In comparison, nano-coating with the combination of chitosan components can prolong the mushroom's shelf-life up to 12 days. In the current study, the application of nano-coating with the combination of chitosan components partially inhibited the oxidative enzyme activities (POD, SOD, and CAT) of mushroom samples due to forming a protective barrier on the mushroom surface and reducing the oxygen supply.

TPC expressed in gallic acid equivalents agreed to these findings ${ }^{19,20}$ which reported that Agaricus bisporus has effective antioxidant activity and can be considered as original natural antioxidants. Eissa ${ }^{21}$, reported TPC changes in button mushrooms during storage of 15 days in cold conditions. The maximum increase was observed on the 3rd day, and then a decrease until the end of the storage period. That can be related to the physiological reaction damage during storage and exposure to oxygen.MDA is generally created by the peroxidation of lipid of the cell membrane as a direct indicator of the membrane injury ${ }^{4}$. The MDA values represented that the coating considerably improved the membrane lipid peroxidations. Therefore, the nano-coating with the combination of chitosan component delayed mushroom senescence and quality deterioration by minimizing the oxidative injury of button mushrooms during the whole storage period.

Respiration occupies the oxidation of energy-rich organic molecules such as organic acids, sugar, and starch into simpler molecules such as carbon dioxide and water with energy production ${ }^{22}$. While the high rate of respiration is associated with the quality loss of the samples. Gholamiet al. ${ }^{23}$, reported similar results for respiration rate which might be an indicator for the spoilage of mushroom samples. Those results indicated that the coating films were extremely efficient in decreasing the mushroom respiration rates.

$\mathrm{CH}-\mathrm{AN}$-SILICA treatment exhibited the highest scavenging against (DPPH) and (ABTS) radicals through enhancing TPC and motivating oxidation activities in treated samples leads to a rise in the antioxidant capacity of mushrooms. Sami et al. ${ }^{24}$, reported that nano-films coatings can efficiently decrease microbial load contamination, deterioration, improve postharvest quality, and prolong the shelf life of white button mushrooms during storage.

Reactive oxygen species mention the oxygen metabolites with high chemical reactivity, such as $\mathrm{OH}, \mathrm{O}_{2}{ }^{--}$, and $\mathrm{H}_{2} \mathrm{O}_{2}$, which are considered as toxic in the plant metabolism, which destroys the cytoplasmic membrane, causes senescence and lipid damage ${ }^{25}$. $\mathrm{OH}$ produced in the human body plays a vital role in tissue injury at sites of inflammation and oxidation for several diseases ${ }^{26}$. The current results declared that coating treatment maintained the lowest hydroxyl radicals activities by the inhibition of hydroxyl radicals of the methanol extract during the storage days. Ding et al. ${ }^{1}$, reported a decrease in $\mathrm{O}_{2}{ }^{--}$production rate was detected in mushroom samples treated with the 4-methoxy cinnamic acid. CH-AN-SILICA with the addition of nisin as an antimicrobial agent preserved almost the reactive oxygen species such as $(\mathrm{OH}-0.33 \mu \mathrm{mol} \mathrm{g}-1),\left(\mathrm{O}_{2}{ }^{--}-0.271 \mathrm{mmol} \mathrm{s}^{-1} \mathrm{~kg}^{-1}\right)$, and $\left(\mathrm{H}_{2} \mathrm{O}_{2}-21.54 \mu \mathrm{mol} \mathrm{g}{ }^{-1}\right)$.

Coating the mushrooms with nisin, nano-silica, and chitosan films had useful effects on the quality and oxidation activities. The results of the current work showed that coatings, especially with nano-silica, were environmentally friendly treatment and efficient in reducing oxidation activities, respiration, and reactive oxygen species during cold storage.

\section{Materials and methods}

Material. Fresh button mushrooms used in this research were carefully selected from the science college laboratory at Taif University, in Taif City. A total number of 160 mushroom caps (forty caps in each basket, three baskets in each group). Mushrooms were in the maturity stage, uniform size, with wholly closed caps, intact, and with no sign of spoilage. They were pre-cooled at $4 \pm 1{ }^{\circ} \mathrm{C}$ and a humidity of $65 \pm 1 \%$ for 24 -h to prevent the growth before the experiment evaluations.

Preparation of films and coating processes. Chitosan powder (85\%), acetic acid, nisin, and nanosilica $(15 \mathrm{~nm})$ were obtained from Sigma Aldrich Company, USA. Chitosan $(\mathrm{CH}-\mathrm{AN})$ as the main coating film was prepared by blending $1 \mathrm{~g}$ in distilled water plus acetic acid $1 \%$ at $(\mathrm{pH}=4)$ and homogenized overnight until ( $\mathrm{pH}=5.5)$. While $\mathrm{CH}$-AN-SILICA film was prepared by blending $1 \%$ nano-silica in $\mathrm{CH}$-AN solution and $\mathrm{CH}-\mathrm{AN}-\mathrm{SILICA} / \mathrm{N}$ film was prepared by blending $1 \%$ of nisin as a safe food additive. The dipping process was applied to coat the mushrooms. Control/M group was dipped well with distilled water for 1 min, while other samples were soaked into the coating films and then dried for $2 \mathrm{~h}$ by an electric fan to lose excess moisture at the ambient temperature. The coated samples were separately packed a zipped lock polyethylene bags and were stored at the cold condition of $4{ }^{\circ} \mathrm{C}^{24}$. Packaged samples were evaluated every 3 days up to 12 days.

Extractions and oxidative enzyme activities assays. Oxidative enzyme activities such as peroxidase (POD), superoxide dismutase (SOD), and catalase (CAT) were evaluated on mushroom samples during storage. Approximately $15 \mathrm{~g}$ of each group were homogenized in $20 \mathrm{~mL}$ of $0.1 \mathrm{~mol}$ phosphate buffer ( $\mathrm{pH} 7.0$ ) and filtered to remove debris from the cells $\mathrm{s}^{27}$. The supernatants were centrifuged at $6000 \mathrm{r} / \mathrm{min}$ for $15 \mathrm{~min}$ at $4{ }^{\circ} \mathrm{C}$ and collected for enzyme activities determinations as follows.

POD activity was determined by the procedure of $\mathrm{Bi}$ et al. ${ }^{28}$ The mixture consisted of $7 \mathrm{~mL}$ of $0.1 \mathrm{~mol}$ $\mathrm{L}^{-1}(\mathrm{pH}=5.5)$ sodium acetate monoacetate buffer, $3 \mathrm{~mL}$ of $25 \mathrm{mmol} \mathrm{L}{ }^{-1}$ guaiacols, and $0.5 \mathrm{~mL}$ mushroom 
supernatants. The absorbance was recorded at $470 \mathrm{~nm}$ after $15 \mathrm{~s}$ as an initial value and recorded continuously every $30 \mathrm{~s}$ until $3 \mathrm{~min}$.

SOD activity was evaluated by the procedure of $\mathrm{Li}$ et al. ${ }^{29}$ The mixture contained $1 \mathrm{~mL}$ of enzyme extract, $0.05 \mathrm{~mol} \mathrm{~L}^{-1} \mathrm{~K}$-phosphate buffer $(\mathrm{pH}=7.8), 0.2 \mathrm{~mL}$ of $750 \mathrm{~mol} \mathrm{~L}^{-1}$ nitro-blue tetrazolium, $0.2 \mathrm{~mL}$ of $130 \mathrm{mmol}$ $\mathrm{L}^{-1}$ methionine $0.2 \mathrm{~mL}$ of $100 \mu \mathrm{mol} \mathrm{L}{ }^{-1}, 0.1 \mathrm{~mL}$ of $\mathrm{mmol} \mathrm{L}^{-1}$ riboflavin and placed under $4000 \mathrm{l} \times$ irradiance at $25^{\circ} \mathrm{C}$ for $1 \mathrm{~h}$. The absorbance was evaluated at $560 \mathrm{~nm}$ and expressed in $\mathrm{U} \mathrm{kg}^{-1}$.

CAT activity was evaluated by the procedure of Liu et al. ${ }^{30}$ The mixture contained $0.1 \mathrm{~mL}$ of enzyme extract, $1 \mathrm{~mL}$ of $0.05 \mathrm{~mol} \mathrm{~L} \mathrm{~L}^{-1}$ sodium phosphate buffer $(\mathrm{pH}=7.8$ ), and $1 \mathrm{~mL}$ of $0.2 \% \mathrm{H} 2 \mathrm{O} 2$. The absorbance was evaluated at $240 \mathrm{~nm}$ at an interval of $30 \mathrm{~s}$ for $3 \mathrm{~min}$ and expressed in $\mathrm{U} \mathrm{kg}^{-1}$.

Determination of total phenolic content (TPC) and malondialdehyde content (MDA). TPC was evaluated according to the method by Sami et al. ${ }^{31}$ In general, $80 \%$ ethanol was blended with $5 \mathrm{~g}$ of each group and centrifuged at $12,000 \mathrm{r} / \mathrm{min}$ for $20 \mathrm{~min}$ at $4{ }^{\circ} \mathrm{C}$. Approximately $2 \mathrm{~mL}$ of $7 \%$ sodium carbonate was blended with $0.8 \mathrm{~mL}$ of collected supernatant and reacted with $1 \mathrm{~mL}$ of Folin-Ciocalteu reagent. The absorbance was evaluated at $760 \mathrm{~nm}$ and gallic acid was used as a standard for the qualifications.

MDA was measured as described by Sami et al. ${ }^{4}$ Approximately $3 \mathrm{~g}$ of each group were blended with $10 \mathrm{~mL}$ of $10 \%$ trichloroacetic acid (TCA) and centrifuged at $12,000 \mathrm{r} / \mathrm{min}$ for $20 \mathrm{~min}$ at $4{ }^{\circ} \mathrm{C}$. The supernatant was mixed with $2 \mathrm{~mL}$ of $0.5 \%$ 2-thiobarbituric acid (TBA), boiled for $15 \mathrm{~min}$, cooled, and evaluated at 450, 532 and $600 \mathrm{~nm}$, respectively.

Respiration rate evaluation. The respiration rate of the mushrooms was detected with a handheld threegas analyzer (F950, FELIX, USA) ${ }^{18}$. Four groups of mushroom samples were put in a confined space in the containers. Two needle-sized holes have been opened in the containers, sealed to avoid the leakage of air, and kept at $4{ }^{\circ} \mathrm{C}$ for $4 \mathrm{~h}$. Consequently, $\mathrm{CO}_{2}$ volume percentage was evaluated in triplicate according to the following formula:

$$
\text { Respiration rate }\left(\mathrm{mg} \mathrm{CO}_{2} \mathrm{~kg}^{-1} \mathrm{~s}^{-1}\right)=\frac{\left(\Delta y_{\mathrm{CO}_{2}} \times V\right)}{(100 \times W \times \Delta t)}
$$

where $\Delta y \mathrm{CO}_{2}$ is the concentration fraction increment $(\%), V(\mathrm{~mL})$ is the free volume, $W(\mathrm{~kg})$ is the mushroom weight, and $\Delta t(\mathrm{~s})$ is the testing time in seconds.

Determination of antioxidant capacity. 2,2-Azino-bis-(3-ethylbenzothiazoline)-6-sulphonate activity (ABTS) was determined according to the mentioned method by Elhakem et al. ${ }^{32,33}$, while 2,2-diphenyl-1-picryhydrazyl activity (DPPH) of treated mushrooms was evaluated by using the method ${ }^{34-36}$ ABTS and DPPH activities in methanol $(\mathrm{MeOH})$ were calculated as a percentage after measuring at 414 and $515 \mathrm{~nm}$, respectively.

Determination of hydroxyl radicals $(\mathrm{OH})$, superoxide anion $\left(\mathrm{O}_{2}{ }^{--}\right)$, and hydrogen peroxide $\left(\mathrm{H}_{2} \mathrm{O}_{2}\right)$. The hydroxyl radical activity of button mushrooms extract was evaluated by the method of Dhanabalan et al. ${ }^{26}$ Stock solution $100 \mu \mathrm{L}$ of $1 \mathrm{mM}$ EDTA was prepared in DMSO and $10 \mu \mathrm{L}$ of $10 \mathrm{mM}$ ferric chloride, 100 $\mu \mathrm{L}$ of $1 \mathrm{mM}$ ascorbic acid, $100 \mu \mathrm{L}$ of $10 \mathrm{mM} \mathrm{H}_{2} \mathrm{O}_{2}, 360 \mu \mathrm{L} 10 \mathrm{mMdeoxyribose}$, and $330 \mu \mathrm{L}$ of $50 \mathrm{mM}$ phosphate buffer $(\mathrm{pH}=7.4)$ were prepared in distilled water. Following incubation for $1 \mathrm{~h}$ at $37^{\circ} \mathrm{C}, 1 \mathrm{~mL}$ of the mixture was added to the reaction solution containing $1 \mathrm{~mL}$ of $10 \%$ tricyclic antidepressant and $1 \mathrm{~mL}$ of $0.5 \%$ thiobarbituric acid, and $1 \mathrm{~mL}$ of $0.025 \mathrm{M} \mathrm{NaOH}$. The absorbance was evaluated at $532 \mathrm{~nm}$ and expressed as $\mu \mathrm{mol} \mathrm{g}^{-1}$.

The rate of $\mathrm{O}_{2}{ }^{--}$production was evacuated according to a commercial kit purchased from (Solarbio, China, Beijing) against $\mathrm{NaNO}_{2}$ as a standard curve previously described by Oyetayo ${ }^{37}$. Approximately $5 \mathrm{~g}$ of mushroom tissues were homogenized with $5 \mathrm{~mL}$ of phosphate buffer, $1 \mathrm{~mL} p$-aminophenylsulfonic acid, $1 \mathrm{~mL}$ a-naphthylamine and centrifuged at $12,000 \mathrm{r} / \mathrm{min}$ for $20 \mathrm{~min}$ at $4{ }^{\circ} \mathrm{C}$. The supernatant was evaluated at $550 \mathrm{~nm}$ and expressed as mmol s $\mathrm{kg}^{-1}$.

The hydrogen peroxide content was evaluated according to the method by Song et al. ${ }^{17}$ Approximately $5 \mathrm{~g}$ of mushroom samples were blended with $30 \mathrm{~mL}$ of acetone $\left(\left(\mathrm{CH}_{3}\right) 2 \mathrm{CO}\right)$, and centrifuged at $10,000 \mathrm{r} / \mathrm{min}$ for $15 \mathrm{~min}$ at $4{ }^{\circ} \mathrm{C}$. HCL (including $200 \mathrm{~mL} \mathrm{~L}^{-1}$ titanium tetrachloride), and ammonia $\left(17 \mathrm{~mol} \mathrm{~L}^{-1}\right)$ were added to the mushroom supernatant then was washed with $\left(\left(\mathrm{CH}_{3}\right) 2 \mathrm{CO}\right)$ and dissolved in $2 \mathrm{~mol} \mathrm{~L} \mathrm{~L}_{2} \mathrm{H}_{2} \mathrm{SO}_{4}$. The absorbance was measured at $410 \mathrm{~nm}$ and expressed as $\mu \mathrm{mol} \mathrm{g} \mathrm{g}^{-1}$.

Statistical analysis. All the current experiments were conducted on three replicates for each treatment. A total of forty white button mushroom caps for each treatment were used. One-way ANOVA test version 8.2 (SAS, Cary, NC, USA) was performed to compare the means at the significance level of $p<0.05$.

Received: 9 January 2021; Accepted: 3 March 2021

Published online: 16 March 2021

\section{References}

1. Ding, Y. et al. Effects of postharvest brassinolide treatment on the metabolism of white button mushroom (Agaricus bisporus) in relation to development of browning during storage. Food Bioprocess Technol. 9, 1327-1334. https://doi.org/10.1007/s11947-0161722-1 (2016). 
2. Karimirad, R., Behnamian, M. \& Dezhsetan, S. Development and characterization of nano biopolymer containing cumin oil as a new approach to enhance antioxidant properties of button mushroom. Int. J. Biol. Macromol. 113, 662-668. https://doi. org/10.1016/j.ijbiomac.2018.02.043 (2018).

3. Sami, R. et al. Effect of titanium dioxide nanocomposite material and antimicrobial agents on mushrooms shelf-life preservation. Processes https://doi.org/10.3390/pr8121632 (2020).

4. Sami, R. et al. Application of nano-titanum dioxide coating on fresh Highbush blueberries shelf life stored under ambient temperature. $L W T$ 137, 110422. https://doi.org/10.1016/j.lwt.2020.110422 (2021).

5. Nur, M. J., Misran, A., Mahmud, T. M. M., Abdullah, S. \& Azhar, M. Evaluation of storage temperature, packaging system and storage duration on postharvest quality of straw mushroom (Volvariella volvacea). Food Res. 4, 679-689. https://doi.org/10.26656 /fr.2017.4(3).349 (2020).

6. Lu, Y. et al. Effects of UV-C irradiation on the physiological and antioxidant responses of button mushrooms (Agaricus bisporus) during storage. Int. J. Food Sci. Technol. 51, 1502-1508. https://doi.org/10.1111/ijfs.13100 (2016).

7. Belay, Z. A., Caleb, O. J. \& Opara, U. L. Modelling approaches for designing and evaluating the performance of modified atmosphere packaging (MAP) systems for fresh produce: a review. Food Packag. Shelf Life 10, 1-15. https://doi.org/10.1016/j.fpsl.2016.08.001 (2016).

8. Parepalli, M. et al. Ganoderma lucidum: extraction and characterization of polysaccharides, yields and their bioapplications. Alger. J. Res. Technol. 5(1), 30-43 (2021).

9. Chen, X. et al. Effects of clove essential oil and eugenol on quality and browning control of fresh-cut lettuce. Food Chem. 214, 432-439. https://doi.org/10.1016/j.foodchem.2016.07.101 (2017).

10. Sami, R. Application of nano-coating and chitosan combination films on cantaloupe preservation. Pak. J. Biol. Sci. 23, 1037-1043. https://doi.org/10.3923/pjbs.2020.1037.1043 (2020).

11. Qu, T. et al. Effect of peppermint oil on the storage quality of white button mushrooms (Agaricus bisporus). Food Bioprocess Technol. $13,1-15(2020)$.

12. Qiao, G., Xiao, Z., Ding, W. \& Sami, R. Effect of chitosan/nano-titanium dioxide/thymol and tween films on ready-to-eat cantaloupe fruit quality. Coatings https://doi.org/10.3390/coatings9120828 (2019).

13. Sami, R., Khojah, E., Elhakem, A., Benajiba, N. \& Helal, M. Chitosan, nisin, silicon dioxide nanoparticles coating films effects on blueberry (Vaccinium myrtillus) quality. Coatings https://doi.org/10.3390/coatings10100962 (2020).

14. Food and Drugs, Chapter I-Food and Drug Administration Department of Health and Human Services. CFR-Code of Federal Regulations. 21, Vol. 3 https://www.accessdata.fda.gov/scripts/cdrh/cfdocs/cfCFR/CFRSearch.cfm?fr=172.480.

15. Sami, R. et al. Evaluation of antioxidant activities, oxidation enzymes, and quality of nano-coated button mushrooms (Agaricus Bisporus) during storage. Coatings 11, 149 (2021).

16. Sami, R. et al. Effect of nano silicon dioxide coating films on the quality characteristics of fresh-cut cantaloupe. Membranes 11(2), $140(2021)$

17. Song, H. et al. Effects of chitosan/nano-silica on postharvest quality and antioxidant capacity of loquat fruit during cold storage. Postharvest Biol. Technol. 119, 41-48. https://doi.org/10.1016/j.postharvbio.2016.04.015 (2016).

18. Hu, Y.-H. et al. Postharvest application of 4-methoxy cinnamic acid for extending the shelf life of mushroom (Agaricus bisporus). Postharvest Biol. Technol. 104, 33-41. https://doi.org/10.1016/j.postharvbio.2015.03.007 (2015).

19. Liu, J., Jia, L., Kan, J. \& Jin, C. H. In vitro and in vivo antioxidant activity of ethanolic extract of white button mushroom (Agaricus bisporus). Food Chem. Toxicol.: Int. J. Publ. Br. Ind. Biol. Res. Assoc. 51, 310-316. https://doi.org/10.1016/j.fct.2012.10.014 (2013).

20. Walkowiak-Tomczak, D., Idaszewska, N., Bieńczak, K. \& Kómoch, W. The effect of mechanical actions occurring during transport on physicochemical changes in Agaricus bisporus mushrooms. Sustainability https://doi.org/10.3390/su12124993 (2020).

21. Eissa, H. A. A. Effect of chitosan coating on shelf life and quality of fresh-cut mushroom. Pol. J. Food Nutr. Sci. 30, 623-645. https ://doi.org/10.1111/j.1745-4557.2007.00147.x (2007).

22. Xu, Y., Tian, Y., Ma, R., Liu, Q. \& Zhang, J. Effect of plasma activated water on the postharvest quality of button mushrooms Agaricus bisporus. Food Chem. 197, 436-444. https://doi.org/10.1016/j.foodchem.2015.10.144 (2016).

23. Gholami, R., Ahmadi, E. \& Farris, S. Shelf life extension of white mushrooms (Agaricus bisporus) by low temperatures conditioning, modified atmosphere, and nanocomposite packaging material. Food Packag. Shelf Life 14, 88-95. https://doi.org/10.1016/j. fpsl.2017.09.001 (2017).

24. Sami, R. et al. Investigating the nano-films effect on physical, mechanical properties, chemical changes, and microbial load contamination of white button mushrooms during storage. Coatings https://doi.org/10.3390/coatings11010044 (2021).

25. Sami, R. Antioxidant properties of peptides from soybean meal protein hydrolysates evaluated by electron spin resonance spectrometry. Adv. Environ. Biol. 11(4), 12-18 (2017).

26. Dhanabalan, M., Sundaram, R. \& Ayyasamy, P. M. Free radical scavenging activity of methanolic extract of Pleurotus florida. Int. J. Pharm. Pharm. Sci. 5, 601-606 (2013).

27. Li, Y. et al. Shelf-life, quality, safety evaluations of blueberry fruits coated with chitosan nano-material films. Sci. Rep. 11, 55. https ://doi.org/10.1038/s41598-020-80056-Z (2021).

28. Bi, X., Wu, J., Zhang, Y., Xu, Z. \& Liao, X. High pressure carbon dioxide treatment for fresh-cut carrot slices. Innov. Food Sci. Emerg. Technol. 12, 298-304. https://doi.org/10.1016/j.ifset.2011.04.001 (2011).

29. Li, P. et al. High carbon dioxide and low oxygen storage effects on reactive oxygen species metabolism in Pleurotus eryngii. Postharvest Biol. Technol. 85, 141-146. https://doi.org/10.1016/j.postharvbio.2013.05.006 (2013).

30. Liu, J., Liu, S., Zhang, X., Kan, J. \& Jin, C. Effect of gallic acid grafted chitosan film packaging on the postharvest quality of white button mushroom (Agaricus bisporus). Postharvest Biol. Technol. 147, 39-47. https://doi.org/10.1016/j.postharvbio.2018.09.004 (2019).

31. Sami, R., Li, C. J., Zhao, Y., Li, Y. \& Sun, C. H. Cabbage (Brassica oleracea L. var. capitata) phytochemicals with antioxidant and anti-inflammatory potential. Asian Pac. J. Cancer Prev.: APJCP 14, 6657-6662. https://doi.org/10.7314/apjcp.2013.14.11.6657 (2014).

32. Elhakem, A. H., Almatrafi, M. M., Benajiba, N., Koko, M. Y. \& Sami, R. Comparative analysis of bioactive compounds, antioxidant and anti-inflammatory activities of apple varieties. Asian J. Plant Sci. 20, 61-66. https://doi.org/10.3923/ajps.2021.61.66 (2020).

33. Elhakem, A. H., Benajiba, N., Khojah, E., Koko, M. Y. \& Sami, R. DPPH, FRAP and TAEC assays with postharvest cabbage (Brassica Oleracca) parameters during the packaging process. Pak. J. Agric. Sci. 24(2), 182-187. https://doi.org/10.3923/pjbs.2021.182.187 (2021).

34. Qiao, G. H. et al. Antioxidant and anti-inflammatory capacities of pepper tissues. Ital. J. Food Sci. 32, 265-274 (2020).

35. Khojah, E. \& Sami, R. Fatty acids composition and oxidative stability of peanut and sesame oils with the sensory evaluation of mayonnaise prepared by different oils. Assiut J. Agric. Sci. 47(6-2), 460-472 (2016).

36. Li, Y. et al. Blending of soybean oil with selected vegetable oils: impact on oxidative stability and radical scavenging activity. Asian Pac. J. Cancer Prev. 16(6), 2583-2589. https://doi.org/10.7314/APJCP.2014.15.6.2583 (2014).

37. Oyetayo, V. O. Free radical scavenging and antimicrobial properties of extracts of wild mushrooms. Braz. J. Microbiol. 40, 380-386. https://doi.org/10.1590/S1517-838220090002000031 (2009). 


\section{Acknowledgements}

Taif University Researchers Supporting Project Number (TURSP-2020/140), Taif University, Taif, Saudi Arabia. This research was funded by the Deanship of Scientific Research at Princess Nourah Bint Abdulrahman University through the Fast-track Research Funding Program.

\section{Author contributions}

R.S. Conceptualization, supervision; R.S., M.H., M.A., M.F. Writing-original draft preparation, Experimental work; A.E. Formal analysis, Editing language; N.B. Investigation; M.H. Resources, Statistical analysis. All authors reviewed the manuscript.

\section{Competing interests}

The authors declare no competing interests.

\section{Additional information}

Correspondence and requests for materials should be addressed to R.S.

Reprints and permissions information is available at www.nature.com/reprints.

Publisher's note Springer Nature remains neutral with regard to jurisdictional claims in published maps and institutional affiliations.

(c) (i) Open Access This article is licensed under a Creative Commons Attribution 4.0 International License, which permits use, sharing, adaptation, distribution and reproduction in any medium or format, as long as you give appropriate credit to the original author(s) and the source, provide a link to the Creative Commons licence, and indicate if changes were made. The images or other third party material in this article are included in the article's Creative Commons licence, unless indicated otherwise in a credit line to the material. If material is not included in the article's Creative Commons licence and your intended use is not permitted by statutory regulation or exceeds the permitted use, you will need to obtain permission directly from the copyright holder. To view a copy of this licence, visit http://creativecommons.org/licenses/by/4.0/.

(C) The Author(s) 2021 